\title{
METODE CERAMAH PLUS DISKUSI DAN TUGAS UNTUK MENINGKATKAN AKTIVITAS BELAJAR SISWA
}

\author{
Hana Maurin ${ }^{1}$, dan Sani Insan Muhamadi ${ }^{1}$ \\ ${ }^{\perp}$ Jurusan Pendidikan Guru Madrasah Ibtidaiyah, UIN Sunan Gunung Djati, Indonesia \\ maurinhana08@gmail.com
}

Naskah diterima: tanggal 5 September 2018, direvisi: tanggal 27 September 2018, diterbitkan: tanggal 31 Oktober 2018

\begin{abstract}
This study aims to determine the learning activities of students before and after using the lecture method plus discussion and assignment. The method used is Classroom Action Research (CAR) through II cycles and each cycle consist of planning, implementation, observation, and reflection, with the number of student 40 people in class IV MI Nurul Huda Sukasari Bandung Regency. Student learning activities before using the lecture method plus discussion and assignment obtained 45,06\% (not god), after using the lecture method plus discussion and assignment to get and increase in each cycle, in the first cycle it reached 61,40\% (good enough) then the student learning activities increased in the cycle II became 92,21\% (very good). Thrus there is a significant increase after using the lecture method plus discussion and assignmenton the moral principles of the noble subject.
\end{abstract}

Keywoards: islamic primary school, method of lecturing plus, student learning activities.

\begin{abstract}
ABSTRAK
Penelitian ini bertujuan untuk mengetahui aktivitas belajar siswa sebelum dan sesudah proses menggunakan metode ceramah plus diskusi dan tugas. Metode yang digunakan adalah penelitian tindakan kelas (PTK) dengan melalui II siklus dan setiap siklusnya terdiri dari perencanaan, pelaksanaan, observasi dan refleksi, dengan jumlah siswa 40 orang di kelas IV MI Nurul Huda Sukasari Kabupaten Bandung. Aktivitas belajar siswa sebelum menggunakan metode ceramah plus diskusi dan tugas memperoleh $45,06 \%$ (tidak baik), setelah menggunakan metode ceramah plus diskusi dan tugas memperoleh peningkatan di setiap siklusnya, pada siklus I mencapai $61,40 \%$ (cukup baik) kemudian aktivitas belajar siswa meningkat pada siklus II menjadi 92,21\% (sangat baik). Dengan demikian terdapat peningkatan yang signifikan setelah menggunakan metode ceramah plus diskusi dan tugas pada mata pelajaran akidah akhlak pokok bahasan akhlak terpuji.
\end{abstract}

Kata Kunci: aktivitas belajar siswa, madrasah ibtidaiyah, metode ceramah plus.

\section{PENDAHULUAN}

Pendidikan menurut Langeveld adalah memberi pertolongan secara sadar dan sengaja kepada seorang anak (yang belum dewasa) dalam pertumbuhannya menuju ke arah kedewasaan dalam arti dapat berdiri sendiri dan bertanggung jawab susila atas tindakannya menurut pilihannya sendiri. (Aisyah, dkk, 2013:4). Menurut Hamalik (Suhada, 2015:7) pembelajaran adalah sebagai suatu kombinasi yang tersusun meliputi unsur-unsur manusiawi, material fasilitas, perlengkapan dari prosedur yang saling mempengaruhi untuk mencapai tujuan pembelajaran. Ketika melaksanakan proses pembelajaran guru sering kali banyak menemukan berbagi masalah yang muncul baik itu tentang cara guru mengajar maupun dari siswanya itu sendiri. Masalah yang terjadi bisa dari faktor mengajar dalam penggunaan metode atau cara pembelajaran guru dalam menyampaikan materi-materi terhadap pembelajaran tersebut. Proses belajar anak tidak hanya mendengarkan saja, tetapi suatu kegiatan untuk menghasilkan pemahaman yang utuh. 
Berdasarkan hasil studi pendahuluan di MI Nurul Huda Sukasari, ditemukan dalam kegiatan pembelajaran guru hanya berpusat pada buku yang ada serta tidak menggunakan pendukung lainnya seperti media atau sumber lain. Peserta didik kurang aktif, kemandirian serta interaksi peserta didik dalam proses pembelajaran tidak tampak sehingga peserta didik cenderung pasif dan tidak komunikatif. Sebagian siswa bercanda, malas-malasan, tidak memperhatikan, ngobrol dengan teman sebangkunya, dan ada beberapa siswa juga yang mengantuk ketika proses belajar mengajar berlangsung.

Banyak metode yang dapat digunakan untuk menangani permasalahan seperti yang diuraikan tersebut, yaitu dengan menggunakan metode pembelajaran yang mampu meningkatkan aktivitas belajar siswa, salah satunya metode pembelajaran ceramah plus diskusi dan tugas. Metode ceramah plus diskusi dan tugas adalah metode mengajar, yaitu Metode ceramah gabungan dengan metode lainnya. Metode ini dilakukan secara tertib sesuai dengan urutannya (Trianto, 2010:135).

Adapun kelebihan dan kekurangan metode ceramah plus dalam pembelajaran menurut Arliny (2012:12) yaitu sebagai berikut.

1. Kelebihan

a. Kelas lebih aktif karena anak tidak hanya mendengarkan saja.

b. Dengan metode ceramah plus ini guru bisa mengontrol urutan dan keluasan materi pembelajaran, sehingga dapat mengetahui sejauh mana siswa menguasai bahan pelajaran yang disampaikan.

c. Metode ini dianggap sangat efektif apabila materi yang harus dikuasai siswa cukup luas, sementara itu waktu yang dimiliki terbatas.

d. Metode ceramah plus ini bisa digunakan untuk jumlah dan ukuran kelas yang besar.

e. Memberikan kesempatan kepada peserta didik untuk bertanya sehingga guru mengetahui hal-hal yang belum dimengerti oleh peserta didik.

2. Kekurangan

a. Dengan adanya tanya jawab kadang-kadang menyimpang dari pokok persoalan bila dalam mengajukan pertanyaan, siswa menyinggung hal-hal lain walaupun masih ada hubungannya dengan pokok yang dibicarakan. Dalam hal ini sering tidak terkendalikan sehingga memunculkan persoalan baru.

b. Memerlukan waktu yang banyak.

c. Metode ini bisa menjadi ceramah murni jika seorang guru tidak cermat dalam penggunaan metode ini.

Aktivitas merupakan kegiatan atau perilaku yang terjadi selama proses pembelajaran. Keaktifan siswa dalam proses pembelajaran akan menyebabkan interaksi antara guru dengan siswa. Aktivitas tersebut menimbulkan terbentuknya pengetahuan dan keterampilan yang mengarah pada prestasi (Sardiman, 2010:45). Menurut Iskandar (dalam Sardiman, 2011:101) aktivitas siswa merupakan keterlibatan peserta didik dalam bentuk sikap, pikiran, perhatian dan aktivitas dalam kegiatan proses pembelajaran guna menunjang keberhasilan proses pembelajaran. Berdasarkan pengertian tersebut peneliti dapat menarik kesimpulan bahwa aktivitas adalah segala bentuk kegiatan yang dilakukan oleh peserta didik di sekolah selama proses pembelajaran berlangsung, serta yang mendukung kegiatan lainnya yang melibatkan fisik dan mental secara bersama-sama.

Menurut Iskandar yang dikutip dari Arikunto (2010) aktivitas siswa merupakan keterlibatan peserta didik dalam bentuk sikap, pikiran, perhatian, dan aktivitas dalam kegiatan proses pembelajaran guna menunjang keberhasilan proses pembelajaran. Menurut Paul D. Dierich (Yuliani, 2015:9) indikator yang menyatakan aktvitas siswa dalam proses belajar mengajar terdiri dari: 
a. Visual activities, yang termasuk didalamnya misalnya, membaca, memperhatikan gambar demonstrasi, percobaan, dan pekerjaan orang lain.

b. Oral activities, seperti: menyatakan, merumuskan, bertanya, memberi saran, mengeluarkan pendapat, mengadakan wawancara, diskusi, dan interupsi.

c. Listening activities, sebagai contoh mendengarkan : uraian, percakapan, diskusi, musik, dan pidato.

d. Writing activities, seperti misalnya: menulis cerita, karangan, laporan, angket, dan menyalin.

e. Drawing activities, misalnya: menggambar, membuat grafik, dan peta diagram.

f. Motor activities, yang termasuk didalamnya antara lain: melakukan percobaan, membuat konstruksi, model mereparasi, bermain, berkebun, dan berternak.

g. Mental activities, sebagai contoh misalnya: menanggapi, mengingat, memecahkan soal, menganalisis, melihat hubungan, dan mengambil keputusan.

h. Emotional activities, seperti misalnya: menaruh minat, merasa bosan, gembira, bersemangat, bergairah, berani, tenang, dan gugup.

Semua kegiatan tersebut merupakan aktivitas siswa, siswa diharapkan berperan aktif dalam mencari suatu informasi guna memecahkan suatu permasalahan. Selain itu ada juga faktor-faktor yang memengaruhi aktivitas belajar siswa diantaranya adalah sebagai berikut:

1. Faktor dari dalam diri individu (internal), meliputi:

a. faktor jasmani;

b. faktor psikologis.

2. Faktor dari luar diri individu (eksternal), meliputi:

a. faktor keluarga;

b. faktor antara hubungan keluarga;

c. suasana rumah;

d. keadaan ekonomi keluarga.

3. Faktor sekolah, meliputi:

a. faktor kurikulum;

b. faktor gedung;

c. waktu sekolah;

d. alat pembelajaran;

e. metode pembelajaran;

f. hubungan antara guru dengan siswa;

g. hubungan antara siswa dengan siswa.

4. Faktor masyarakat

Kehidupan masyarakat di sekitar tempat tinggal siswa merupakan salah satu faktor yang dapat berpengaruh terhadap belajar anak. Jika siswa berada di lingkungan yang baik yaitu berada disekitar orang-orang terpelajar, berbudi pekerti baik, akan berpengaruh baik bagi siswa. Dengan semikian, akan menjadi pendorong untuk belajar, serta dapat mendorong motivasi. Tetapi, jika seorang siswa berada di lingkungan yang tidak baik seperti berada di sekitar orang-orang yang tidak terpelajar, malas, berbuat kebiasaan yang tidak baik, seperti berjudi dan mengonsumsi narkoba, maka bisa berpengaruh tidak baik kepada anak.

Akidah akhlak adalah salah satu mata pelajaran yang di ajarkan di Madrasah Ibtidaiyah. Pembelajaran akidah akhlak adalah upaya sadar dan terencana dalam menyiapkan peserta didik untuk mengenal, memahami, menghayati dan mengimani Allah Swt. dan merealisasikan perilaku akhlak mulia dalam kehidupan sehari-hari berdasarkan Alquran dan Hadist melalui kegiatan, bimbingan, pengajaran, latihan, serta penggunaan 
pengalaman (Haq, 2012:11). Adapun salah satu materi pembelajaran akidah akhlak di MI kelas IV yaitu mengenai pokok bahasan akhlak terpuji, yaitu: sifat wajib yang dimiliki Nabi dan Rasul, yaitu sifat sidiq, amanah, fathanah dan tabligh.

Adapun hipotesis dalam penelitian ini adalah penerapan metode ceramah plus diskusi dan tugas diduga dapat meningkatkan aktivitas belajar siswa pada mata pelajaran akidah akhlak pokok bahasan akhlak terpuji di kelas IV MI Nurul Huda Sukasari Kecamatan Kertasari Kabupaten Bandung.

Adapun hasil penelitian yang relevan dalam penelitian adalah sebagai berikut.

1. Penelitian Tindakan Kelas yang dilakukan oleh Mardani (2017:87) yang berjudul "Penerapan Metode Sosiodrama untuk Meningkatkan Aktivitas Belajar Siswa pada Mata Pelajaran Akidah Akhlak Pokok Bahasan Indahnya Berperilaku Terpuji“. Hasil penelitian menunjukkan bahwa aktivitas belajar siswa meningkat menjadi lebih baik pada setiap siklus, yakni pada siklus 1 diperoleh rata-rata 58,1\% (sedang), siklus II diperoleh rata-rata 78,77\% (baik), dan siklus III diperoleh rata-rata 86,27\% (sangat baik)

2. Penelitian yang dilakukan oleh Junierissa (2016) yang berjudul "Pengaruh Penerapan Metode Ceramah Plus dengan Metode Resitasi Terhadap Motivasi Belajar Mahasiswa Bimbingan Konseling Universitas Riau Kepulauan Batam". Hasil penelitian menunjukkan bahwa motivasi belajar dapat ditingkatkan melalui metode pengajaran ceramah plus dan metode pengajaran resitasi. Penelitian ini menunjukkan pentingnya melaksanakan metode pengajaran yang sesuai dengan kebutuhan mahasiswa sehingga dapat meningkatkan hasil belajar mahasiswa.

3. Penelitian yang di lakukan oleh Erlita (2012) yang berjudul "Pengaruh Pendidikan Kesehatan dengan Metode Ceramah Plus Diskusi dan Tugas (CPDT) terhadap Sikap Remaja Putri di SMPN 29 Surabaya". Berdasarkan hasil penelitian yang dilakukan oleh Eerlita tersebut bahwa terdapat pengaruh positif terhadap sikap remaja putri tentang pencegahan keputihan dengan menggunakan metode CPDT.

4. Penelitian tindakan kelas yang dilakukan oleh Yuliani (2015) yang berjudul "Penerapan Metode Peta Konsep untuk Meningkatkan Aktivitas Belajar Siswa pada Mata Pelajaran IPS Pokok Bahasan Peristiwa Sekitar Proklamasi di kelas V'. Berdasarkan hasil pengamatan tersebut, diperoleh data bahwa aktivitas belajar siswa mengalami peningkatan yang baik dengan persentase pra siklus yaitu $51 \%$ (cukup), siklus I yaitu $76,2 \%$ (baik), dan siklus II yaitu 96,8\% (sangat baik).

5. Penelitian yang dilakukan Sudana (2017) yang berjudul "Upaya Meningkatkan Hasil Belajar PAI Materi Pokok Kisah Khalifah Abu Bakar Ra Melalui Penerapan Metode Ceramah Plus Diskusi dan Tugas pada Siswa Kelas V SD Negeri 01 Blumbang Kecamatan Tawangmangu Semester 2 Tahun Pelajaran 2016/2017'. Hasil penelitian menunjukkan pada siklus I diperoleh hasil yang kurang/tidak tuntas. Berdasarkan hal tersebut, peneliti menerapkan metode ceramah plus dan diskusi. Kemudian peneliti menerapkan metode tersebut di siklus II dengan memanfaatkan media video cerita sahabat Kholifah Abu Bakar as Shiddiq Ra. Peningkatan hasil belajar siklus I adalah $44 \%$ dan siklus II adalah $89 \%$. Peningkatan nilai rata-rata $69,4 \%$ dan pada siklus II adalah $81,1 \%$. Kesimpulan dari penelitian tersebut adalah penerapan metode ceramah plus diskusi dan tugas dapat meningkatkan hasil belajar siswa kelas V pada pembelajaran PAI materi pokok kisah sahabat Kholifah Abu Bakar as Shiddiq Ra.

Metode yang peneliti lakukan ini berbeda dengan yang sebelumnya, yaitu untuk peningkatan aktivitas siswa dalam proses pembelajaran menjadi lebih baik serta untuk menambah dan mengembangkan pengetahuan, wawasan, dan pengalaman bagi guru yang khususnya bagi peneliti itu sendiri. Adapun manfaat bagi lembaga yaitu dengan adanya 
kegiatan yang dilakukan serta hasil yang diberikan dapat membawa dampak positif terhadap perkembangan sekolah yang nampak pada peningkatan aktivitas belajar. Dengan demikian ketuntasan belajar minimal yang telah ditetapkan oleh sekolah dapat tercapai, yaitu peningkatan aktivitas belajar siswa. Dengan meningkatkan keberhasilan siswa berarti meningkatkan mutu bagi sekolah tersebut, serta memberikan banyak pengalaman dalam menghadapi dan mengatasi segala permasalahan yang ditemui dalam kegiatan pembelajaran.

\section{METODOLOGI}

Metode yang digunakan dalam penelitian ini adalah metode Penelitian Tindakan Kelas (Classroom Action Research), yang dilakukan dengan tujuan memperbaiki dan meningkatkan mutu praktik pembelajaran dikelas (Arikunto, 2010:58). Salahudin (2015:24) menjelaskan bahwa penelitian tindakan kelas adalah salah satu upaya guru atau praktisi dalam bentuk berbagai kegiatan yang dilakukan untuk memperbaiki dan meningkatkan mutu pembelajaran di kelas. Penelitian ini merupakan bentuk reflektif berupa tindakan tertentu agar dapat memperbaiki praktik pembelajaran di kelas secara efektif dan efisien serta profesional.

Desain penelitian tindakan kelas ini dilakukan dalam beberapa siklus. Langkahlangkah yang dilakukan dalam penelitian ini menurut Hopkins dalam Arikunto (2009:16) bahwa PTK terdiri dari empat tahap, yaitu: (1) perencanaan (planning), (2) tindakan (acting), (3) pengamatan (oberving), dan (4) refleksi (reflecting).

Adapun model dan penjelasan untuk masing-masing tahap adalah sebagai berikut.

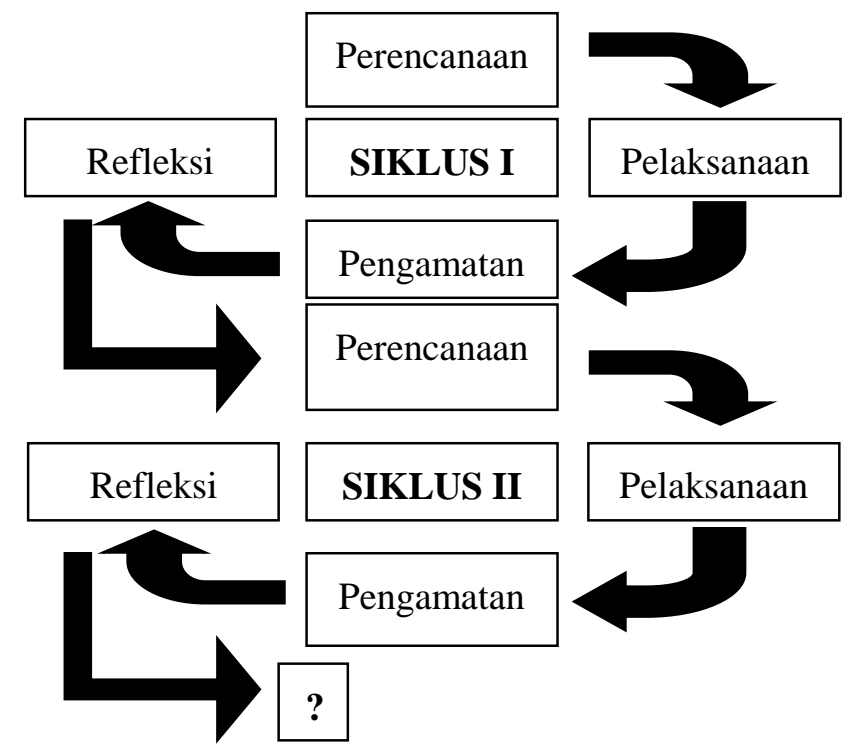

Gambar 1. Model Penelitian Tindakan Kelas Model Arikunto

Penelitian tindakan kelas ini direncanakan dalam dua siklus yang saling berkaitan, untuk lebih jelasnya berikut rincian siklus yang akan dilaksanakan adalah sebagai berikut.

Pada siklus I tindakan yang dilakukan yaitu:

1. Tahap perencanaan (planning)

Rencana pelaksanaaan PTK mencakup beberapa kegiatan berikut:

a. merencanakan pembelajaran,

b. mempersiapkan Rencana Pelaksanaan Pembelajaran (RPP),

c. mempersiapkan sumber pembelajaran,

d. mempersiapkan format observasi pembelajaran. 


\section{Tahap pelaksanaan (acting)}

Pada tahap ini langkah-langkah pembelajaran dan tindakan mengacu pada perencanaan yang telah dibuat yaitu peneliti melaksanakan tindakan sesuai dengan rencana pelaksanaan pembelajaran dan tujuan pembelajaran yang ingin dicapai.

3. Tahap pengamatan (observing)

Pengamatan dilakukan pada saat pelaksanaan pembelajaran berlangsung. Pengamatan ini bertujuan untuk mengetahui aktifitas siswa selama proses pembelajaran. Hasil pengamatan dituangkan dalam lembar pengamatan aktivitas siswa.

4. Refleksi (reflecting)

Tahap ini dimaksudkan untuk mengkaji secara menyeluruh tindakan yang telah dilakukan, berdasarkan data yang terkumpul dan kemudian melakukan evaluasi guna menyempurnakan tindakan yang berikutnya. Apabila kegiatan tidak tercapai maka akan dilakukan siklus selanjutnya.

Pada siklus II tindakan yang dilakukan adalah:

1. Tahap perencanaan (planning)

Rencana pelaksanaan PTK mencakup beberapa kegiatan berikut:

a. penentuan alternatif pemecahan masalah,

b. mempersiapkan skenario pembelajaran Rencana Pelaksanaan Pembelajaran (RPP) untuk pelaksanaan pembelajaran ke dua.

2. Tahap Pelaksanaan (Acting)

Tindakan PTK pada siklus II berupa pelaksanaan pembelajaran kedua sesuai skenario pembelajaran.

3. Tahap Pengamatan (Observing)

Melihat perkembangan pembelajaran dan membandingkannya dengan pembelajaran sebelumnya.

4. Tahap Refleksi (Reflecting)

Kegiatan yang dilakukan pada tahap refleksi siklus II adalah melihat ketercapaian pembelajaran, dan melihat perubahan belajar siswa.

Adapun penelitian ini dilaksanakan di MI Nurul Huda Sukasari Kecamatan Kertasari Kabupaten Bandung. Pemilihan tempat penelitian didasarkan karena masih rendahnya aktivitas belajar siswa pada mata pelajaran Akidah Akhlak di kelas IV. Waktu penelitian ini akan dilaksanakan pada bulan Maret 2018 sampai dengan selesai, yaitu pada semester genap yang disesuaikan dengan materi pembelajaran yang peneliti gunakan.

Jenis data yang dikumpulkan dalam penelitian ini adalah data kualitatif dan kuantitatif. Action research termasuk penelitian kualitatif walaupun data yang digunakan dapat bersifat kuantitatif (Salahudin, 2015:20). Data kualitatif merupakan data yang berupa kalimatkalimat atau data yang dikategorikan berdasarkan kualitas data objek yang diteliti, meliputi observasi dan wawancara dengan pihak-pihak yang bersangkutan. Data kuantitatif adalah data yang berupa angka-angka atau bilangan. Adapun data kuantitatif ini didapatkan dari hasil belajar baik itu pada pra siklus, siklus I, maupun siklus II di kelas IV MI Nurul Huda Sukasari pada mata pelajaran akidah akhlak.

Sumber data menurut Mahmud (2011:152) terbagi kedalam dua bagian, yaitu:

a. Sumber Data Primer 
Sumber data primer adalah sumber data pokok yang langsung dikumpulkan dari subjek penelitian yang dapat memberikan informasi terhadap penelitian yang akan dilaksanakan, yaitu data yang diperoleh dari data kelas IV MI Nurul Huda Sukasari yang berjumlah 40 orang, yaitu 20 orang laki-laki dan 20 orang perempuan.

b. Sumber Data Sekunder

Sumber data sekunder adalah sumber data tambahan yang menunjang data pokok, yaitu guru atau wali kelas yang diajak berkerja sama berkolaborasi sebagai observer dalam penelitian tindakan kelas dengan melakukan kegiatan observasi aktivitas belajar siswa dan aktivitas guru selama proses pembelajaran berlangsung.

Adapum untuk memperoleh data yang diperlukan, peneliti menggunakan teknik pengumpulan data dengan lembar observasi, wawancara, dan studi dokumentasi.

1. Observasi

Observasi adalah suatu teknik yang dilakukan dengan cara mengadakan pengamatan secara teliti dan sistematis terhadap fenomena-fenomena yang sedang dijadikan sasaran pengamatan. Observasi dapat menilai atau mengukur proses dan hasil belajar (Hayati, 2013:77). Observasi digunakan untuk mengetahui keterlaksanaan aktivitas siswa selama proses pembelajaran berlangsung dengan menggunakan metode ceramah plus diskusi dan tugas pada mata pelajaran akidah akhlak dengan menggunakan lembar observasi yang telah dibuat berdasarkan indikator-indikator yang akan diobservasikan.

2. Wawancara

Menurut Esterberg dalam Sugiyono (2013:231) wawancara merupakan pertemuan dua orang untuk bertukar informasi dan ide melalui tanya jawab, sehingga dapat dikontruksikan makna dalam suatu topik tertentu. Wawancara ini dilakukan untuk mendapatkan keterangan atau pendapat mengenai sesuatu hal yang diperlukannya untuk tujuan tertentu, dari seorang guru, kepala sekolah, dan pihak lain dengan cara tanya jawab, yaitu mengenai kegiatan aktivitas belajar siswa, kondisi objektif sekolah dan lain sebagainya.

3. Studi Dokumentasi

Studi Dokumentasi adalah teknik pengumpulan data yang tidak langsung ditujukan kepada subjek penelitian dalam rangka memperoleh informasi terkait objek penelitian. Menurut Sugiyono (2013:240) studi dokumen merupakan catatan peristiwa yang sudah berlalu. Studi Dokumen bisa berbentuk tulisan, gambar, atau karya-karya monumental dari seorang. Dokumen yang berbentuk tulisan seperti catatan harian, sejarah kehidupan (life histories), ceritera, biografi, peraturan, kebijakan. Dokumen yang berbentuk gambar misalnya foto, gambar hidup, sketsa dan lain-lain. Dokumentasi merupakan pelengkap dari penggunaan metode observasi dan wawancara dalam penelitian.

Adapun analisis yang digunakan dalam penelitian ini yaitu analisis observasi aktivitas guru dan siswa dianalisis menggunakan rumus sebagai berikut:

a. Menghitung jumlah skor aktivitas siswa yang telah diperoleh

$$
\text { Skor }=\frac{\text { Jumlah Aktivitas Tiap Siswa }}{\text { Skor Ideal }} \times 100 \%
$$

b. Menghitung nilai rata-rata dari aktivitas siswa dengan menggunakan rumus sebagai berikut:

$$
\begin{aligned}
& X=\frac{\Sigma X}{N} \\
& \text { Keterangan : } \\
& \mathrm{X}=\text { Rata-rata nilai seluruh aktivitas siswa }
\end{aligned}
$$


$\Sigma \mathrm{x}=$ jumlah seluruh nilai siswa

$\mathrm{N}=$ Jumlah seluruh siswa

c. Mengubah skor yang diperoleh menjadi nilai persentase dengan rumus :

$$
\text { Persentase }=\frac{\text { Rata }- \text { rata Aktivitas Siswa }}{\text { Jumlah No Item } \times \text { Skor Maksimal }} \times 100 \%
$$

Rumus Aktivitas Guru:

$$
\text { Aktivitas Guru selama KBM }=\frac{\text { jumlah Aktivitas Guru }}{\text { Jumlah Item }} \times 100 \%
$$

Adapun untuk menghitung Hasil observasi aktivitas siswa dan guru yang terdiri dari dua tindakan pada setiap siklus digunakan rumus:

$$
=\frac{\text { Hasil Observasi Tindakan } 1+\text { Hasil Observasi Tindakan } 2}{2}
$$

\begin{tabular}{|c|c|}
\hline Kriteria & Kategori \\
\hline $86 \%-100 \%$ & Sangat Baik \\
\hline $76 \%-85 \%$ & Baik \\
\hline $60 \%-75 \%$ & Cukup Baik \\
\hline $55 \%-59 \%$ & Kurang Baik \\
\hline$<54 \%$ & Tidak Baik \\
\hline
\end{tabular}

Sumber: Purwanto (2012), dalam Yuliani,2015:23)

\section{HASIL DAN DISKUSI}

a. Aktivitas Belajar Siswa dan Guru Pra Siklus

Berdasarkan hasil observasi aktivitas belajar siswa sebelum menggunakan metode ceramah plus diskusi dan tugas, diperoleh presentase $45,06 \%$ dengan kategori $<54 \%$ "tidak baik" atau dilihat dari kriteria keterlaksanaan pembelajaran hasil ini menunjukkan aktivitas belajar siswa pada mata pelajaran akidah akhlak "cukup aktif".

Berdasarkan persentase hasil observasi aktivitas guru pada pra siklus menunjukkan bahwa aktivitas guru selama pembelajaran sebelum menggunakan metode ceramah plus diskusi dan tugas termasuk ke dalam kriteria cukup baik dengan perolehan nilai $66,67 \%$.

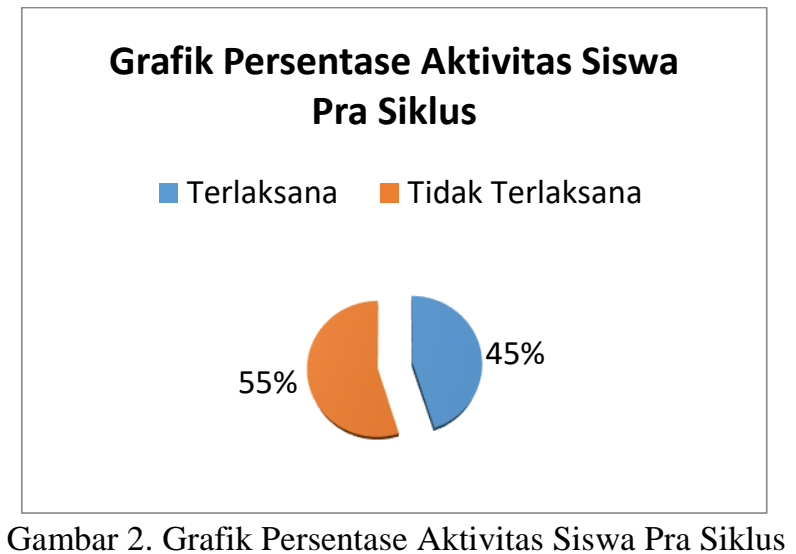




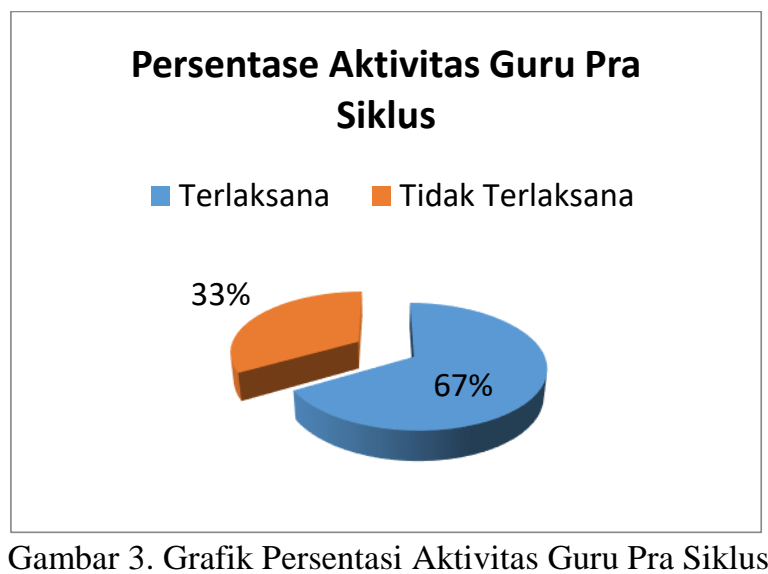

b. Aktivitas Belajar Siswa dan Guru Siklus I

Berdasarkan persentase hasil observasi aktivitas guru pada siklus I menunjukkan bahwa aktivitas guru selama pembelajaran menggunakan metode ceramah plus diskusi dan tugas termasuk ke dalam kriteria baik dengan perolehan nilai rata-rata sebesar $76,47 \%$ dan indikator yang belum tercapai sebesar $23,53 \%$. Berdasarkan persentase hasil observasi aktivitas siswa menunjukkan bahwa aktivitas siswa selama mengikuti kegiatan pembelajaran pada siklus I termasuk ke dalam kategori baik dengan perolehan nilai $61,4 \%$ dan indikator yang belum tercapai sebesar 38,6\%.

Aspek ketercapaian yang belum maksimal pada siklus I dikarenakan masih kurangnya aktivitas belajar siswa dan guru dengan menggunakan metode yang diterapkan oleh guru. Pembelajaran masih terasa kurang menyenangkan dan tahapantahapan model pembelajaran ini tidak tersampaikan dengan maksimal. Oleh karena itu, aktivitas guru dan siswa masih harus ditingkatkan pada siklus II agar seluruh tahapan dapat tersampaikan secara maksimal.

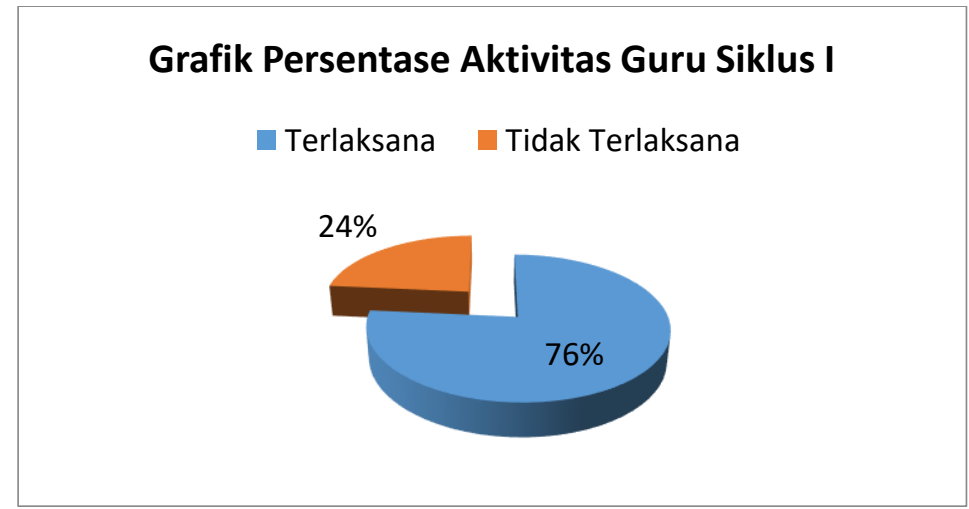

Gambar 4. Grafik Persentase Aktivitas Guru Siklus I 


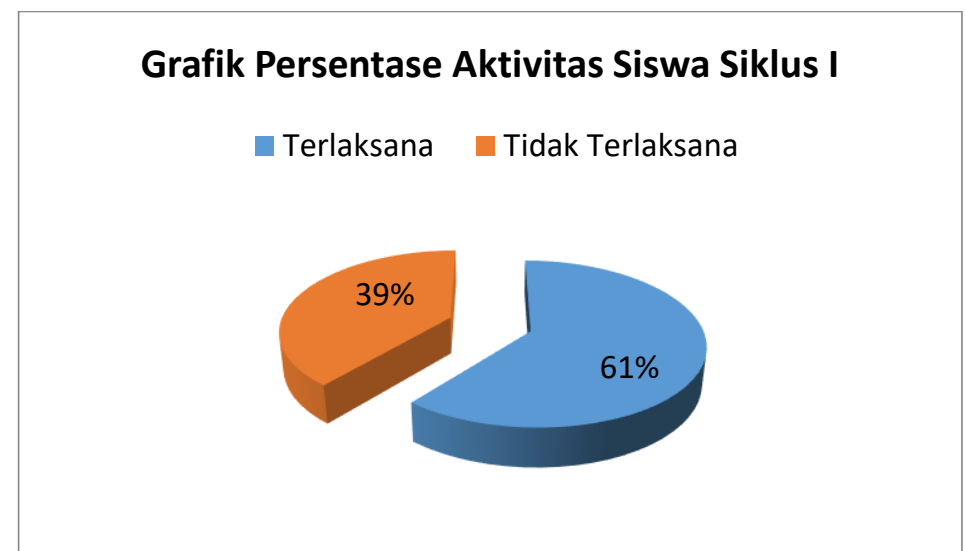

Gambar 5. Grafik Persentase Aktivitas Siswa Siklus I

\section{c. Aktivitas Belajar Siswa dan Guru Siklus II}

Berdasarkan persentase hasil observasi aktivitas guru pada siklus II menunjukkan bahwa aktivitas guru selama pembelajaran menggunakan metode ceramah plus diskusi dan tugas termasuk ke dalam kriteria sangat baik dengan perolehan nilai sebesar $94,11 \%$. Berdasarkan Persentase hasil observasi aktivitas siswa menunjukkan bahwa aktivitas siswa selama mengikuti kegiatan pembelajaran pada siklus II termasuk ke dalam kategori Sangat baik dengan perolehan nilai sebesar $92,21 \%$.

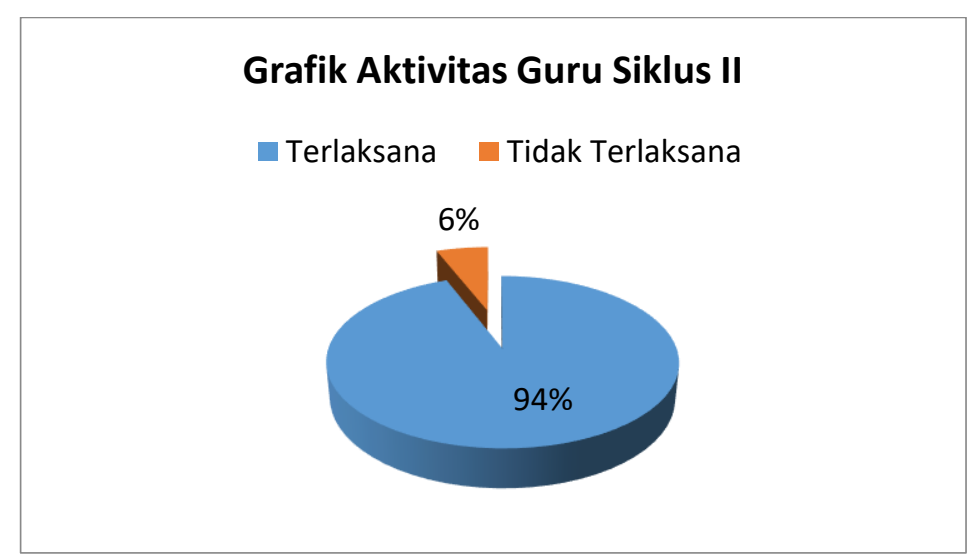

Gambar 6. Grafik Aktivitas Guru Siklus II

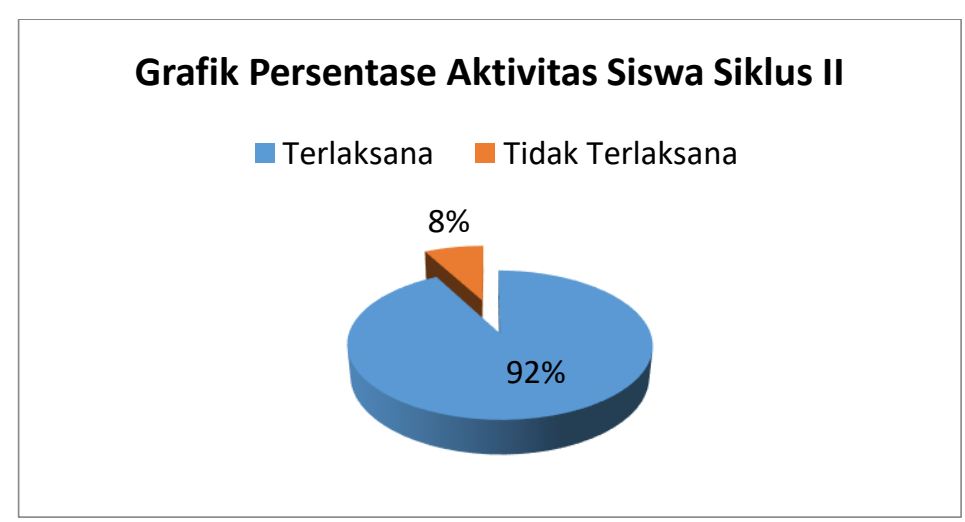

Gambar 7. Grafik Persentase Aktivitas Siswa Siklus II

d. Aktivitas Belajar Siswa dan Guru Setelah Menggunakan Metode 
Penggunaan metode ceramah plus diskusi dan tugas ternyata membawa hasil yang memuaskan, aktivitas belajar siswa sebelum menggunakan metode hanya memperoleh nilai persentase sebesar $45,06 \%$, sedangkan setelah menggunakan metode aktivitas belajar siswa sangat meningkat dengan perolehan nilai sebesar $92,21 \%$ dengan kategori $>85 \%$ yang berarti sangat baik atau dilihat dari kategori presentase sangat aktif.

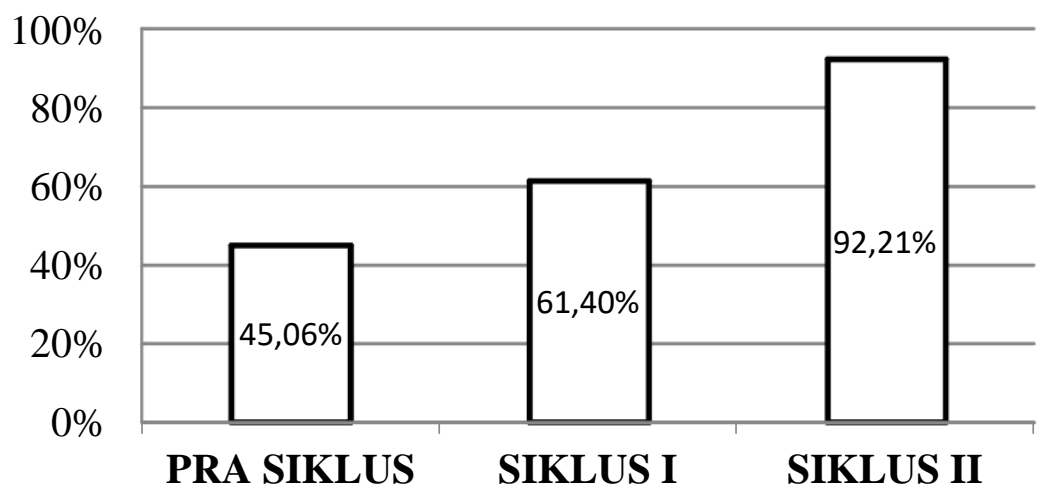

Gambar 8. Grafik Persentase Aktivitas Siswa

\section{KESIMPULAN}

Berdasarkan hasil penelitian tindakan kelas untuk meningkatkan aktivitas belajar siswa pada mata pelajaran akidah akhlak pokok bahasan akhlak terpuji melalui metode ceramah plus diskusi dan tugas yang dilaksanakan di MI Nurul Huda Sukasari Kelas IV Kabupaten Bandung. Aktivitas belajar siswa pada mata pelajaran akidah akhlak pokok bahasan akhlak terpuji sebelum diterapkan metode ceramah plus diskusi dan tugas belum terlaksana dengan baik sebagaimana yang diharapkan. Hal itu bisa dilihat pada situasi kelas yang tidak kondusif, gaduh, serta masih banyak siswa yang tidak mau diam ke sana ke mari, sehingga nilai aktivitas belajar siswa hanya memperoleh $45,06 \%$ dinyatakan "tidak baik" dengan ratarata 33,8. Proses penerapan metode ceramah plus diskusi dan tugas pada mata pelajaran akidah akhlak pokok bahasan akhlak terpuji pada siklus I belum terlaksana dengan baik sebagaimana diharapkan, karena masih ada beberapa langkah-langkah pembelajaran yang belum terlaksana secara baik, tetapi sudah ada peningkatan semula $61,40 \%$ (cukup baik), jika dilihat dari kriteria keterlaksanaan aktivitas belajar siswa $<80$ (aktif) dan meningkat pada Siklus II menjadi 92,21\% (sangat baik), jika dilihat dari kriteria keterlaksanaan aktivitas belajar siswa $>80$ (sangat aktif). Aktivitas belajar siswa pada mata pelajaran akidah akhlak pokok bahasan akhlak terpuji sesudah diterapkan metode ceramah plus diskusi dan tugas pada akhir siklus aktivitas belajar siswa mengalami perubahan yang sangat bagus, siswa memperoleh nilai $92,21 \%$, dari data tersebut dapat dilihat peningkatan aktivitas yang signifikan. Hal ini membuktikan bahwa metode ceramah plus diskusi dan tugas dapat meningkatkan aktivitas belajar siswa pada materi akhlak terpuji. Berdasarkan hasil penelitian yang meliputi aktivitas belajar siswa pada pra-siklus dan aktivitas siswa dan guru pada setiap siklus dalam materi akhlak terpuji. Ada beberapa saran dalam rangka meningkatkan aktivitas belajar siswa, yaitu guru sebaiknya menciptakan suasana yang menyenangkan dan guru sebaiknya menciptakan fasilitator yang memegang peranan penting dalam memilih metode pembelajaran agar proses pembelajaran lebih kondusif sehingga siswa memperoleh hasil yang baik. Metode ceramah plus diskusi dan tugas merupakan metode yang dapat digunakan dalam proses pembelajaran untuk meningkatkan aktivitas belajar siswa. 


\section{DAFTAR PUSTAKA}

Aisyah, A. \& Rohaniawati, D. (2013). Landasan Pendidikan. Bandung: Alfabeta. Arikunto, S. dkk (2010). Penelitian Tindakan Kelas. Jakarta: PT Bumi Aksara. Hayati, T. (2013). Evaluasi Pembelajaran. Bandung: CV. Insan Mandiri.

Kusuma R, Erlita. (2012). Pengaruh pendidikan kesehatan dengan metode ceramah plus diskusi dan tugas (CPDT) terhadap sikap remaja putri di SMPN 29 Surabaya. Retrieved From: http://ejurnaladhkdr.com/index.php/coba/article/view/11/pdf.

Mahmud (2013). Metode Penelitian Pendidikan. Bandung: CV Pustaka Setia

Mardiani, Anis Sani, (2017). Penerapan Metode Sosiodrama Untuk Meningkatkan Aktivitas Belajar Siswa Pada Mata Pelajaran Akidah Akhlak Pokok Bahasan Indahnya Berperilaku Terpuji. UIN Sunan Gunung Djati Bandung.

Marpaung, Junierissa (2016). Pengaruh Penerapan Metode Ceramah plus dengan Metode Resitasi Terhadap Motivasi Belajar Mahasiswa Bimbingan Konseling Universitas Riau Kepulauan Batam. Retrieved From http://www. Journal.unrika.ac/pdf.

Nurul Haq, Dadan dan Hasbiyallah. (2012). Pendidikan Akidah Akhlak. Bandung: Fajar Media.

Salahudin, Anas. (2015). Penelitian Tindakan Kelas. Bandung: Pustaka Setia.

Sardiman, (2010). Interaksi dan motivasi belajar mengajar. Jakarta: Raja Grafindo Persada.

Sudana. (2017). Upaya Meningkatkan Hasil Belajar PAI Materi Pokok Kisah Khalifah Abu Bakar Ra Melalui Penerapan Metode Ceramah Plus Diskusi dan Tugas Pada Siswa Kelas V Sd Negeri 01 Blumbang Kecamatan Tawangmangu Semester 2 Tahun Pelajaran 2016/2017. Retrieved From http://jurnal.ijer.web.id/index.php/ijer/article/viewfile/pdf.

Sugiyono. (2013). Metode Penelitian Kuantitatif dan Kualitatif. Bandung: Alfabeta.

Suhada, Idad. (2017). Konsep Dasar IPS. Bandung: CV Insan Mandiri.

Trianto. (2010). Mengembangkan Model Pembelajaran Tematik. Jakarta: PT. Prestasi Pustakaraya.

Yuliani. (2015). Penerapan Metode Peta Konsep untuk Meningkatkan Aktivitas Belajar Siswa pada Mata Pelajaran IPS Pokok Bahasan Peristiwa Sekitar Proklamasi. Uin Sunan Gunung Djati Bandung. 